\title{
PENERAPAN PRINSIP-PRINSIP GOOD GOVERNANCE DALAM PENYELENGGARAAN REFORMA AGRARIA DI INDONESIA
}

\author{
Muhammad Ilham Arisaputra \\ Pengamat Hukum \\ ilham_arisaputra@gmail.com
}

\begin{abstract}
Agrarian reform is one of solutions to overcome the poverty. The agrarian reform needs a political commitment from the government. In addition, agrarian information is important to figure out the problems and its potential to overcome the problems. Agrarian reform can not depend on the authority and political power of the government only, it also needs the involvement of the community and other stakeholders. In the context of regional authonomy, the authority of agrarian reform will be the authority of the local government, therefore the involvement of the community in every stage is necessary. National Planning for Agrarian Reform Programme should be conformed with the characteristics of the region and the inputs from the stakeholders, since they understand the situation and the agrarian problems in the region.
\end{abstract}

Keywords: agrarian reform, stakeholders, landreform.

\begin{abstract}
Abstrak
Pentingnya melakukan reformasi agraria sebagai salah satu solusi mengatasi persoalan kemiskinan agraria ternyata tidak mudah untuk diterjemahkan secara praktis. Proses penataan struktur agraria, selain memerlukan kekuatan politik pemerintah yang solid (termasuk militer) juga memerlukan informasi yang memadai menyangkut persoalan dan potensi agraria itu sendiri. Pelaksanaan reformasi agraria tidak bisa sepenuhnya menggunakan kewenangan dan kekuatan politik pemerintah semata, akan tetapi perlu juga melibatkan partisipasi masyarakat dan pihak-pihak lain yang terkait dengan pelaksanaan reformasi agraria. Dalam konteks otonomi daerah, kewenangan pelaksanaan landreform menjadi kewenangan daerah sehingga keterlibatan masyarakat sejak awal perlu mendapatkan penekanan yang serius. Perencanaan Program Reformasi Agraria Nasional harus disesuaikan dengan karakteristik suatu wilayah dengan melibatkan masukan stakeholders di wilayah mana akan dilaksanakan program, karena mereka lebih mengerti dengan kondisi wilayah mereka sehingga kegiatannya lebih fokus dengan permasalahan yang dihadapi daerah tersebut.
\end{abstract}

Kata kunci : reformasi agraria, stakeholders, landreform

\section{Pendahuluan}

Tanah adalah karunia dari Tuhan Yang Maha Esa kepada umat manusia dimuka bumi. Tanah menjadi kebutuhan dasar manusia. Sejak lahir sampai 
meninggal dunia, manusia membutuhkan tanah untuk tempat tinggal dan sumber kehidupan. Dalam sejarah peradaban umat manusia, tanah merupakan faktor yang paling utama dalam menentukan produksi setiap fase peradaban. Tanah tidak hanya memiliki nilai ekonomis yang tinggi, tetapi juga nilai filosofis, sosial, kultural, dan ekologis. Tak mengherankan jika tanah menjadi harta istimewa yang tak henti-hentinya memicu berbagai masalah sosial yang kompleks dan rumit. Tanah merupakan kebutuhan hidup manusia yang sangat mendasar. Manusia hidup serta melakukan aktivitas di atas tanah sehingga setiap saat manusia selalu berhubungan dengan tanah. Dapat dikatakan hampir semua kegiatan hidup manusia baik secara langsung maupun tidak langsung selalu memerlukan tanah. Pada saat manusia meninggal dunia masih memerlukan tanah untuk penguburannya.

Begitu pentingnya tanah bagi kehidupan manusia, maka setiap orang akan selalu berusaha memiliki dan menguasainya. Dengan adanya hal tersebut, maka dapat menimbulkan suatu sengketa mengenai tanah di dalam masyarakat. Masalah pertanahan di Indonesia tidak bisa di tangani dan diselesaikan dengan menggunakan pendekatan hukum saja, melainkan dengan pendekatan holistik (komperehensif) seperti politik, sosial budaya, ekonomi (kesejahteraan) dan ekologi. Yang tidak kalah penting adalah penanganan dan penyelesaian konflik dilapangan harus didukung oleh kelembagaan pertanahan yang kuat dan berwibawa, koordinasi antar instansi pemerintah yang efektif, administrasi pertanahan yang berbasis teknologi dan penerapan prinsip-prinsip good governance, manajemen konflik yang efektif dan efisien, strategi penanganan dan penyelesaian yang cepat, tepat dan efektif ditopang sumber daya manusia yang handal dengan kemampuan terlatih, baik di pusat maupun di daerah.

Menyadari nilai dan arti penting tanah, para pendiri Negara Kesatuan Republik Indonesia (NKRI) merumuskan tentang tanah dan sumber daya alam secara ringkas tetapi filosofis substansial di dalam Konstitusi Pasal 33 ayat (3) Undang-Undang Dasar Negara Republik Indonesia Tahun 1945 (selanjutnya disingkat UUD 1945) bahwa "Bumi dan air dan kekayaan alam yang terkandung di dalamnya dikuasai oleh negara dan dipergunakan untuk sebesar-besar 
kemakmuran rakyat". Masalah pertanahan muncul ketika kewenangan (hak menguasai negara) diperhadapkan dengan hak asasi warga negara, khususnya hak milik individu dan hak komunal (tanah ulayat). Mencermati konflik pertanahan di Indonesia yang terus meningkat, akar masalahnya terketak pada benturan antara Hak Menguasai Negara (HMN) dengan hak asasi warga negara (HAM) yang memiliki kewenangan tunggal yang sangat besar untuk mengelola pembagian, penguasaan, pemanfaatan dan peruntukkan tanah harus berhadapan dengan hakhak asasi yang melekat pada rakyatnya sendiri. Sengketa konflik pertanahan yang semakin marak dan kompleks belakangan ini terlihat sangat jelas.

Reformasi agraria merupakan upaya untuk memberi penguatan aset masyarakat yang berupa tanah, dan sekaligus upaya meningkatkan akses masyarakat terhadap tanah. Dalam perspektif manajemen, reformasi agraria merupakan format pelayanan Badan Pertanahan Nasional Republik Indonesia kepada masyarakat. Meskipun reformasi agraria merupakan kebutuhan masyarakat, namun ia merupakan kewajiban negara dalam penyelenggaraannya. Walaupun merupakan kewajiban negara, namun pelaksanaan reformasi agraria tetap saja sangat membutuhkan partisipasi masyarakat. Sebagai format pelayanan, maka reformasi agraria memiliki tantangan sebagai berikut:

1. Reformasi agraria haruslah mudah (esier). Pelaksanaan reformasi agraria hendaklah dapat mudah dipahami oleh banyak pihak, termasuk masyarakat. Untuk itu diperlukan formula yang memenuhi logika dan rasionalitas masyarakat.

2. Reformasi agraria haruslah cepat (faster). Pelaksanaan reformasi agraria hendaklah tidak terlalu lama atau jangan ditunda-tunda lagi, sebab akan kehilangan momentum. Penundaan reformasi agraria akan membangkitkan konflik sosial yang akan mengganggu harmoni kebangsaan.

3. Reformasi agraria haruslah murah (cheaper). Pelaksanaan reformasi agraria hendaklah dapat dijangkau oleh anggaran negara, baik melalui anggaran pemerintah pusat, maupun anggaran pemerintah daerah.

4. Reformasi agraria haruslah lebih baik (better). Pelaksanaan reformasi agraria hendaklah dapat memberikan upaya optimal bagi pencapaian keadilan dalam 
penguasaan, pemilikan, penggunaan, dan pemanfaatan tanah. Dengan demikian akan tercipta struktur penguasaan, pemilikan, penggunaan, dan pemanfaatan tanah yang lebih adil.

5. Reformasi agraria haruslah memenuhi prinsip-prinsip penyelenggaraan pemerintahan yang baik (good governance). Pelaksanaan reformasi agraria yang memenuhi prinsip-prinsip ini akan lebih dapat dipertanggungjawabkan kepada masyarakat.

\section{Good Governance}

Istilah governance tidak sama dengan government. Ganie-Rochman mengemukakan bahwa konsep "government" menunjuk pada suatu organisasi pengelolaan berdasarkan kewenangan tertinggi (negara dan pemerintah). Konsep "governance" melibatkan tidak sekedar pemerintah dan negara, tetapi juga peran berbagai aktor diluar pemerintah dan negara, sehingga pihak-pihak yang terlibat juga sangat luas. ${ }^{1}$ Paulus Effendi Lotulung mengemukakan bahwa "Konsep governance dalam masyarakat sering dirancukan dengan konsep government. Konsep governance lebih inklusif daripada government. Konsep government menunjuk pada suatu organisasi pengelolaan berdasarkan kewenangan tertinggi (Negara dan pemerintah). Konsep governance melibatkan tidak sekedar pemerintah dan negara, sehingga pihak-pihak yang terlibat juga sangat luas".2

Kasman Abdullah mengemukakan bahwa good governance sebagai suatu terminologi yang populer sejak awal tahun sembilan puluhan, seolah-olah formula yang baru diketemukan untuk terapi mekanisme pemerintahan suatu negara agar berjalan secara demokratis. Good governance dengan begitu saja disamaartikan dan telah menggeser terminologi lama, yaitu good government, yang dipandang tidak mujarab lagi. Dalam penyelenggaraan pemerintahan, good governance sesungguhnya bukanlah suatu formula yang baru, melainkan suatu asas atau

\footnotetext{
${ }^{1}$ Joko Widodo, Good Governance; Telaah Dari Dimensi Akuntabilitas, Kontrol Birokrasi Pada Era Desentralisasi Dan Otonomi Daerah, Surabaya: Insan Cendekia, 2001, h. 18

${ }^{2}$ Paulus Effendi Lotulung, Tata Kepemerintahan yang Baik (Good Governance) Dalam Korelasinya Dengan Hukum Administrasi, dalam Philipus M. Hadjon, et.al., Hukum Administrasi dan Good Governance, Jakarta: Universitas Trisakti, 2012, h. 37.
} 
prinsip yang telah berusia ratusan tahun dan yang seharusnya menjadi sendi-sendi pemerintahan dalam negara demokrasi modern, yaitu bagaimana penyelenggaraan pemerintahan tersebut mengedepankan prinsip partisipasi, transparansi, dan akuntabilitas, serta membuka ruang bagi keterlibatan warga masyarakat. ${ }^{3}$

The United Development Programme (UNDP) mendefinisikan kepemerintahan (governance) sebagai Governance is the exercise of economic, political, and administrative authory to manage a country's affairs at all levels and means by which states promote social cohesion, integration, and ensure the well being of their population. ${ }^{4}$ Lebih lanjut UNDP menegaskan bahwa "It is complex mechanisms, process, relationships, and institutions trough which citizens and groups articulate their interest, exercise their rights and obligations and mediate their differences". 5

Lembaga Administrasi Negara (LAN) mengartikan good governance sebagai proses penyelenggaraan kekuasaan negara dalam melaksanakan penyediaan public goods and services. ${ }^{6}$ Lebih lanjut LAN menegaskan bahwa dilihat dari segi functional aspect, governance dapat ditinjau dari apakah pemerintah telah berfungsi secara efektif dan efisien dalam upaya mencapai tujuan yang telah digariskan atau sebaliknya. ${ }^{7}$

Good dalam good governance menurut LAN mengandung dua pengertian. Pertama, nilai-nilai yang menjunjung tinggi keinginan/ kehendak rakyat dan nilainilai yang dapat meningkatkan kemampuan rakyat yang dalam pencapaian tujuan (nasional) kemandirian, pembangunan berkelanjutan dan keadilan sosial. Kedua, aspek-aspek fungsional dari pemerintahan yang efektif dan efesien dalam pelaksanaan tugasnya untuk mencapai tujuan-tujuan tersebut. Wujud good governance menurut LAN adalah penyelenggaraan pemerintahan negara yang solid dan bertanggung jawab serta efisien dan efektif dengan menjaga

\footnotetext{
${ }^{3}$ Abdullah, Kasman, Penyelenggaraan Pemerintahan Dalam Konsep Good Governance, Jurnal Meritokrasi Vol. 1 No. 1, Makassar: Fakultas Hukum Universitas Hasanuddin, 2002, h. 65.

4 Sedarmayanti, Good Governance (Kepemerintahan Yang Baik), Bagian Kedua, Bandung: CV. Mandar Maju, 2004, h. 3.

5 Joko Widodo, Op.Cit., h. 19

${ }^{6}$ Ibid, h. 23.

${ }^{7}$ Ibid, h. 24 .
} 
"kesinergisan" interaksi yang konstruktif diantara domain-domain negara, sektor swasta dan masyarakat. ${ }^{8}$

UNDP dalam workshopnya menyimpulkan bahwa "that good governance system are participatory, implying that all members of governance institution have a voice in influencing decision-making”. Sistem kepemerintahan yang baik adalah partisipasi, yang menyatakan bahwa semua anggota institusi governance memiliki suara dalam mempengaruhi pembuatan keputusan. Hal ini merupakan fondasi legitimasi dalam sistem demokrasi. Prosedur dan metode pembuatan keputusan harus transparan (transparant) agar supaya memungkinkan terjadinya partisipasi efektif. Siapa saja yang dipilih untuk membuat keputusan dalam pemerintahan, organisasi bisnis dan organisasi masyarakat sipil (business and civil society organizations) harus bertanggung jawab kepada publik, serta kepada institusi stakeholders. Institusi governance harus efisien dan efektif dalam melaksanakan fungsi-fungsinya, responsif terhadap kebutuhan rakyat, memfasilitasi (fasilitative) dan memberi peluang (enabling) ketimbang mengkontrol (controling), melaksanakan sesuai dengan peraturan perundangan (the rule of law). ${ }^{9}$

Bank Dunia memberi batasan good governance sebagai pelayanan publik yang efisien, sistem peradilan yang dapat diandalkan, serta pemerintahan yang bertanggung jawab pada publiknya. ${ }^{10}$ Gerald Meier memberikan pengertian good governance, yaitu "prinsip mengatur pemerintahan yang memungkinkan layanan publiknya efisien, sistem pengadilannya bisa diandalkan, dan administrasinya bertanggung jawab pada publik, dan dimana mekanisme pasar merupakan pertimbangan utama dalam proses pembuatan keputusan mengenai alokasi sumberdaya". 11

Selanjutnya Sedarmayanti mengelompokkan unsur-unsur kepemerintahan (governance stakeholders) ke dalam 3 kategori, yaitu:

\footnotetext{
${ }^{8}$ Ibid, h. 23-24.

${ }^{9}$ Ibid, h. 24.

${ }^{10}$ Ari Dwipayana, Op.Cit., h. 18.

${ }^{11}$ Kasman Abdullah, Op.Cit., h. 69.
} 
a. Negara/Pemerintahan; konsepsi kepemerintahan pada dasarnya adalah kegiatan kenegaraan, tetapi lebih jauh dari itu melibatkan pula sektor swasta dan kelembagaan masyarakat madani (Civil Society Organization).

b. Sektor Swasta; pelaku sektor swasta mencakup perusahaan swasta yang aktif dalam interaksi dalam sistem pasar, seperti: industri pengolahan (manufacturing), perdagangan, perbankan, dan koperasi, termasuk kegiatan sektor informal.

c. Masyarakat Madani (Civil Society); kelompok masyarakat dalam konteks kenegaraan pada dasarnya berada di antara atau di tengah-tengah antara pemerintah dan perseorangan, yang mencakup baik perseorangan maupun kelompok masyarakat yang berinteraksi secara sosial, politik dan ekonomi. ${ }^{12}$

Menurut Jimly Asshiddiqie dalam sistem negara modern yang berdasarkan pada supremasi hukum dan konstitusi, negara, pasar, dan masyarakat madani harus berada dalam kedudukan yang harus seimbang, dan berada dalam hubungan sinergis dan secara fungsional saling menunjang. ${ }^{13}$ Akan tetapi, pembedaan diantara ketiganya dianggap penting, sehingga ketiganya tidak saling mengintervensi ke dalam urusan masing-masing. Ketiga wilayah atau domain kekuasaan itu mempunyai logika dan hukum-hukumnya sendiri. Ketiganya diidealkan harus berjalan seiring dan sejalan, sama-sama kuat dan sama-sama saling mengendalikan satu sama lain, tetapi tidak boleh saling mencampuri atau dicampuradukkan. ${ }^{14}$

Jika kekuasaan negara melampaui kekuasaan masyarakat (civil society) dan pasar (market), demokrasi dinilai tidak akan tumbuh karena terlalu didikte dan dikendalikan oleh kekuasaan negara. Jika kekuasaan pasar terlalu kuat, melampaui kekuasaan civil society dan negara, berarti kekuatan uanglah atau kaum kapitalislah yang menentukan segalanya dalam prikehidupan bermasyarakat dan bernegara. Tetapi, jika kekuasaan yang dominan adalah civil society,

\footnotetext{
${ }^{12}$ Sedarmayanti, Op.Cit., h. 38.

${ }^{13}$ Jimly Asshiddiqie, Konstitusi dan Konstitusionalisme Indonesia, Jakarta: PSHTN FHUI, 2004, h. 92.

14 Jimly Asshiddiqie, Format Kelembagaan Negara dan Pergeseran Kekuasaan Dalam UUD 1945, Yogyakarta: FH-UII Press, 2005, h. 43.
} 
sementara negara dan pasar lemah, maka yang akan terjadi adalah kehidupan bersama yang chaos, messy, government-less, yang berkembang tanpa arah yang jelas. Karena itu, yang dianggap paling ideal untuk demokrasi adalah apabila ketiga wilayah kekuasaan itu tumbuh secara seimbang, sama-sama kuat dan saling pengaruh mempengaruhi satu sama lain dalam hubungan yang fungsional dan sinergis. Jika salah satu di antaranya paling dominan dibanding yang lain maka yang lain menjadi lemah. Sebagai ilustrasi, jika negara kuat atau mempunyai pengaruh besar untuk mengatasi berbagai permasalahan yang timbul dalam kehidupan bersama dibanding civil society dan swasta, maka keputusannya akan otoriter atau terjadi tindakan yang repressif, sebaliknya jika civil society (masyarakat madani) lebih kuat dibanding yang lain, maka keputusan-keputusan lembaga-lembaga negara substansinya akan dipengaruhi oleh tekanan-tekanan massa, demikian pula halnya jika pasar (market) atau swasta lebih kuat, maka akan menciptakan ketidakteraturan dalam kehidupan bernegara dan bermasyarakat. $^{15}$

Menurut Miftah Thoha, selain dari komponen pemerintah, swasta, dan rakyat, satu komponen yang amat menentukan untuk melahirkan tata kepemerintahan yang baik adalah moral. Moral menghubungkan ketiga komponen tersebut yang saling berinteraksi menciptakan tata kepemerintahan yang baik. Moral merupakan operasionalisasi dari sikap dan pribadi seseorang yang beragama. Ajaran agama melekat pada pribadi-pribadi yang berada pada ketiga komponen tersebut. Dengan melaksanakan ajaran agamanya pada masing-masing komponen tersebut, maka moral masing-masing pelaku akan berperan besar sekali dalam menciptakan tata pemerintahan yang baik. ${ }^{16}$

\section{Asas-Asas Umum Pemerintahan Yang Baik}

Dalam mewujudkan kepemerintahan yang baik (good governance) dalam pemerintahan daerah, maka pemerintah daerah sebagai unsur utama penyelenggara pemerintahan yang merupakan pengayom dan pelayan masyarakat

\footnotetext{
${ }^{15}$ Ibid.

${ }^{16}$ Miftah Thoha, Op.Cit., h. 72.
} 
sudah seharusnya menjunjung tinggi Asas Umum Pemerintahan Negara yang Baik sesuai dengan Undang-Undang Nomor 28 Tahun 1999 tentang Penyelenggaraan Pemerintahan yang Bersih dan Bebas dari Kolusi, Korupsi, dan Nepotisme (UU No. 28/1999). Dalam Pasal 1 ayat (6) UU No. 28/1999 dijelaskan bahwa "Asas Umum Pemerintahan Negara yang Baik adalah asas yang menjunjung tinggi norma kesusilaan, kepatuhan, dan norma hukum, untuk mewujudkan Penyelenggaraan Negara yang bersih dan bebas dari korupsi, kolusi, dan nepotisme".

Dalam bahasa Belanda, Asas Umum Pemerintahan yang baik dikenal dengan istilah Algemene Beginselen van Behoorlijk Bestuur dan ditempatkan dalam Undang-undang Umum Hukum Administrasi (Algemene wet Bestuursrecht) yang meliputi Prosedural Norms dan Subtantive Norms. ${ }^{17}$ Asas Umum Pemerintahan yang baik ini lebih mengikat secara moral karena asas-asas tersebut belum pernah dituangkan secara resmi dalam peraturan perundangundangan sebagai asas-asas umum pemerintahan, sehingga kekuatan hukumnya secara yuridis formal belum ada. ${ }^{18}$ Asas-Asas Umum Pemerintahan Yang Baik ini diuraikan oleh Koentjoro Purbopranoto ${ }^{19}$ ke dalam tiga belas asas yaitu:

1. Azas kepastian hukum (Principle of Legal Security).

2. Azas keseimbangan (Principle of Proportionality).

3. Azas kesamaan dalam mengambil keputusan (Principle of Equality).

4. Azas bertindak cermat (Principle of Carefulness).

5. Azas motivasi untuk setiap keputusan (Principle of Motivation).

6. Azas jangan mencampur-adukkan kewenangan (Principle of Non Misuse of Competence).

7. Azas permainan yang layak (Principle of Fair Play).

8. Azas keadilan atau kewajaran (Principle of Reasonable or Prohibition of

\footnotetext{
${ }^{17}$ Lihat pendapat G.J. Brouwer dan A.E. Schilder, A Survey of Dutch Administrative Law, Nijmegen: Ars Aequi Libri, 1998, h. 34-46, dalam Tatiek Sri Djatmiati, Perizinan sebagai Instrumen Yuridis Dalam Pelayanan Publik, Pidato Pengukuhan Guru Besar Dalam Bidang Hukum Administrasi Pada Fakultas Hukum Universitas Airlanggadi Surabaya pada tanggal 24 November 2007, h. 9.

18 SF. Marbun dan Moh. Mahfud MD, Pokok-Pokok Hukum Administrasi Negara, Yogyakarta: Liberty, 2000, h. 58.

${ }^{19} \mathrm{Ibid}$, h. 59.
} 
Arbitrariness).

9. Azas menanggapi pengharapan yang wajar (Principle of Meeting Raised Expectation).

10. Azas meniadakan akibat suatu keputusan yang batal (Principle of Undoing The Consequences of An Annulled Decision).

11. Azas perlindungan atas pandangan (cara) hidup pribadi (Principle of Protecting The Personal Way of Life).

12. Azas kebijaksanaan (Sapientia).

13. Azas penyelenggaraan kepentingan umum (Principle of Public Service).

Selain itu penyelenggaraan pemerintahan harus pula dilandasi oleh asasasas umum penyelenggaraan negara sesuai dengan Pasal 3 UU No. 28/1999 yang meliputi Asas Kepastian Hukum, Asas Tertib Penyelenggaraan Negara, Asas Kepentingan Hukum, Asas Keterbukaan, Asas Proporsionalitas, Asas Profesionalitas, dan Asas Akuntabilitas. Asas-asas ini kemudian dijelaskan dalam Penjelasan Pasal 3 UU No. 28/1999 yaitu sebagai berikut:

Angka 1

Yang dimaksud dengan "Asas Kepastian Hukum" adalah asas dalam Negara hukum yang mengutamakan landasan peraturan perundangundangan, kepatutan, dan keadilan dalam setiap kebijakan Penyelenggara Negara.

Angka 2

Yang dimaksud dengan "Asas Tertib Penyelenggaraan Negara" adala asas yang menjadi landasan keteraturan, keserasian, dan keseimbangan dalam pengendalian Penyelenggara Negara.

Angka 3

Yang dimaksud dengan “Asas Kepentingan Umum” adalah asas yang mendahulukan kesejahteraan umum dengan cara yang aspiratif, akomodatif, dan selektif.

Angka 4

Yang dimaksud dengan "Asas Keterbukaan" adalah asas yang membuka diri terhadap hak masyarakat untuk memperoleh informasi yang benar, jujur, dan tidak diskriminatif tentang penyelenggaraan negara dengan tetap memperhatikan perlindungan atas hak asasi pribadi, golongan, dan rahasia Negara.

Angka 5

Yang dimaksud dengan "Asas Proporsionalitas" adalah asas yang mengutamakan keseimbangan antara hak dan kewajiban Penyelenggara Negara.

Angka 6 
Yang dimaksud dengan "Asas Profesionalitas" adalah asas yang mengutamakan keahlian yang berlandaskan kode etik dan ketentuan peraturan perundang-undangan yang berlaku.

Angka 7

Yang dimaksud dengan “Asas Akuntabilitas' adalah asas yang menentukan bahwa setiap kegiatan dan hasil akhir dari kegiatan penyelenggaraan negara harus dapat dipertanggungjawabkan kepada masyarakat atau rakyat sebagai pemegang kedaulatan tertinggi negara sesuai dengan ketentuan peraturan perundang-undangan yang berlaku.

United Nations Development Programme (UNDP) sebagaimana yang dikutip oleh Lembaga Administrasi Negara mengajukan karakteristik good governance, sebagai berikut:

1. Participation. Setiap warga Negara mempunyai suara dalam pembuatan keputusan, baik secara langsung maupun melalui intermediasi institusi legitimasi yang mewakili kepentingannya. Partisipasi seperti ini dibangun atas dasar kebebasan berasosiasi dan berbicara serta berpartisipasi secara konstruktif.

2. Rule of Law. Kerangka hukum harus adil dan dilaksanakan tanpa pandang bulu, terutama hukum untuk hak asasi manusia.

3. Transparancy. Transparansi dibangun atas dasar kebebasan arus informasi. Proses-proses, lembaga-lembaga dan informasi secara langsung dapat diterima oleh mereka yang membutuhkan. Informasi harus dapat dipahami dan dapat dimonitor.

4. Responsiveness. Lembaga-lembaga dan proses-proses harus mencoba untuk melayani setiap "stakeholders".

5. Consensus Orientation. Good Governance menjadi perantara kepentingan yang berbeda untuk memperoleh pilihan-pilihan terbaik bagi kepentingan yang lebih luas baik dalam hal kebijakan-kebijakan maupun prosedurprosedur.

6. Equity. Semua warga Negara, baik laki-laki maupun perempuan, mempunyai kesempatan untuk meningkatkan atau menjaga kesejahteraan mereka. 
7. Effectiveness and Efficiency. Proses-proses dan lembaga-lembaga sebaik mungkin menghasilkan sesuai dengan apa yang digariskan dengan menggunakan sumber-sumber yang tersedia.

8. Accountability. Para pembuat keputusan dalam pemerintahan, sektor swasta dan masyarakat (civil society) bertanggung jawab kepada publik dan lembagalembaga "stakeholders". Akuntabilitas ini tergantung pada organisasi dan sifat keputusan yang dibuat, apakah keputusan tersebut untuk kepentingan internal atau eksternal organisasi.

9. Strategic Vision. Para pemimpin dan publik harus mempunyai perspektif good governance dan pengembangan manusia yang luas dan jauh ke depan sejalan dengan apa yang diperlukan untuk pembangunan semacam ini. ${ }^{20}$

Dari karakteristik yang dikemukakan oleh UNDP tersebut, Sedarmayanti menyimpulkan bahwa terdapat empat unsur atau prinsip utama yang dapat memberi gambaran administrasi publik yang berciri kepemerintahan yang baik yaitu sebagai berikut:

1. Akuntabilitas: Adanya kewajiban bagi aparatur pemerintah untuk bertindak selaku penanggung jawab dan penanggung gugat atas segala tindakan dan kebijakan yang ditetapkannya.

2. Transparansi: Kepemerintahan yang baik akan bersifat transparan terhadap rakyatnya, baik di tingkat pusat maupun daerah.

3. Keterbukaan: Menghendaki terbukanya kesempatan bagi rakyat untuk mengajukan tanggapan dan kritik terhadap pemerintah yang dinilainya tidak transparan.

4. Aturan hukum: Kepemerintahan yang baik mempunyai karakteristik berupa jaminan kepastian hukum dan rasa keadilan masyarakat terhadap setiap kebijakan publik yang ditempuh. ${ }^{21}$

Berbicara tentang penerapan good governance pada sektor publik juga tidak dapat terlepas dari visi Indonesia masa depan sebagai fokus tujuan pembangunan kepemerintahan yang baik. Pemerintah yang baik dapat dikatakan $38-40$

${ }^{20}$ Joko Widodo, Op.Cit., h. 25. Lihat pula dalam Philipus M. Hadjon, et.al., Op.Cit., h.

${ }^{21}$ Sedarmayanti, Op.Cit., h. 7. 
sebagai pemerintah yang menghormati kedaulatan rakyat, memiliki tugas pokok yang mencakup mlindungi segenap bangsa Indonesia dan seluruh tumpah darah Indonesia, memajukan kesejahteraan umum, mencerdaskan kehidupan bangsa, melaksanakan ketertiban dunia yang berdasarkan kemerdekaan, perdamaian abadi, dan keadilan sosial. Semua itu sudah seharusnya dijadikan landasan bagi pemerintah daerah dalam menyelenggarakan pemerintahan sehingga dapat terwujud kepemerintahan yang baik sesuai dengan prinsip-prinsip good governance.

\section{Prinsip Good Governance Dalam Pelaksanaan Reforma Agraria}

Reforma Agraria adalah restrukturisasi (penataan ulang susunan) kepemilikan, penguasaan, dan penggunaan sumber-sumber agraria (khususnya tanah). Tujuannya adalah untuk mengubah susunan masyarakat warisan stelsel feodalisme dan kolonialisme menjadi susunan masyarakat yang adil dan merata. Secara etimologis reforma agraria berasal dari bahasa Spanyol, yang memiliki arti suatu upaya perubahan atau perombakan sosial yang dilakukan secara sadar, guna mentransformasikan struktur agraria ke arah sistem agraria yang lebih sehat dan merata bagi pengembangan pertanian dan kesejahteraan masyarakat desa. ${ }^{22}$ Istilah Pembaruan Agraria baru diperkenalkan di Tahun 2001, yakni sejak lahirnya Tap MPR Nomor IX/MPR/2001 tentang Pembaruan Agraria dan Pengelolaan Sumber Daya Alam, yang berarti bahwa istilah Reforma Agraria (Agrarian Reform) lebih dulu dikenal dalam wacana ilmiah dibandingkan istilah Pembaruan Agraria. ${ }^{23}$

Krishna Ghimire memberikan pengertian yang asama antara agrarian reform dan landreform. Dalam bukunya yang berjudul Land Reform \& Peasant Livelihoods: The Social Dynamics of Rural Poverty \& Agrarian Reform In Developing Countries Tahun 2001, ia mendefinisikan reformasi agraria atau landreform sebagai perubahan besar dalam struktur agraria yang membawa peningkatan akses petani miskin pada lahan serta kepastian penguasaan (tenure) bagi mereka yang menggarap lahan, termasuk juga akses pada input pertanian,

\footnotetext{
${ }^{22}$ Gunawan Wiradi, Reformasi Agraria; Perjalanan Yang Belum Berakhir, Yogyakarta: INSIST Press; 2000, h. 35.

${ }^{23}$ Bernhard Limbong, Reforma Agraria, Jakarta: Margaretha Pustaka, 2012, h. 26.
} 
pasar, serta jasa-jasa dan kebutuhan pendampingan lainnya ${ }^{24}$. Reformasi agraria merupakan suatu perubahan dalam struktur agraria dengan tujuan peningkatan akses kaum tani miskin akan penguasaan tanah dan untuk meningkatkan kesejahteraan kaum tani miskin. ${ }^{25}$

Pasal 2 Tap MRP Nomor IX/MPR/2001 tentang Pembaruan Agraria dan Pengelolaan Sumber Daya Alam menjelaskan bahwa Pembaruan agraria mencakup suatu proses yang berkesinambungan berkenaan dengan penataan kembali penguasaan, pemilikan, penggunaan dan pemanfaatan sumber daya agraria, dilaksanakan dalam rangka tercapainya kepastian dan perlindungan hukum serta keadilan dan kemakmuran bagi seluruh rakyat Indonesia. Secara tidak langsung Pasal 2 ini memberikan definisi mengenai Pembaruan agraria yang dimana pembaruan agraria dimaknai dengan proses yang berkesinambungan berkenaan dengan penataan kembali penguasaan, pemilikan, penggunaan dan pemanfaatan sumber daya agraria.

Frithjof Kuhnen menandai reformasi agraria sebagai tindakan untuk mengatasi hambatan pembangunan yang timbul karena adanya kecacatan dalam struktur agraria yang berlaku. ${ }^{26}$ Reformasi agraria harus bermakna penataan ulang struktur penguasaan tanah yang mencakup redistribusi tanah dan pembatasan (pencegahan) konsentrasi penguasaan tanah dan bahkan dapat pula di dalamnya terkandung aksi-aksi untuk menata ulang sistem bagi hasil dalam kegiatan pertanian. $^{27}$

Ben Cousins memberikan perbedaan antara agrarian reform dengan landreform. Landreform berkaitan dengan hak atas tanah dengan cirinya masingmasing, kekuatan dan distribusi. Sedangkan reformasi agraria tidak terbatas pada konsep landreform tersebut, tetapi lebih luas mencakupi juga isu-isu karakter kelas dari hubungan antara produksi dan distribusi di bidang pertanian dan perusahaan yang terkait, dan bagaimana semua hal itu terhubung ke struktur kelas

\footnotetext{
${ }^{24}$ Anonim, Hakekat Reformasi Agraria http://www.berdikarionline.com/opini/20111231/hakekat-reformasi-agraria.html\#ixzz2JY1hdWzT diunduh 2 Februari 2014.

${ }^{25}$ Bernhard Limbong, Op.Cit., h. 27.

${ }^{26}$ Lihat Frithjof Kuhnen dalam Bernhard Limbong.

${ }^{27}$ Ibid.
} 
yang lebih luas. Dengan kata lain, reformasi agraria berkaitan dengan kekuatan ekonomi dan politik dan hubungan antara keduanya. Reformasi agraria pada konteks ini harus mencakup:

1. Instrumen kebijakan agraria yang karakter kualitatif dan seterusnya mengacu pada perubahan yang lebih kecil seperti subsidi, tarif pajak, dan sebagainya.

2. Perubahan struktural untuk mengubah struktur pertanian, seperti program kredit, investasi di bidang infrastruktur, penyuluhan, dan sebagainya.

3. Reformasi kelembagaan yang mengubah dasar ekonomi pedesaan dan masyarakat, seperti rdistribusi tanah, perubahan penyewaan, kolektivisasi, dan sebagainya. $^{28}$

Dengan demikian pada hakikatnya, konsep reformasi agraria mencakup 3 konsep, yakni:

1. Konsep Landreform, yakni penataan kembali struktur penguasaan kepemilikan tanah yang lebih adil.

2. Konsep Acces reform, yakni berkaitan dengan penataan penggunaan atau pemanfaatan tanah yang lebih produktif disertai penataan dukungan sarana dan prasarana yang memungkinkan petani memperoleh akses ke sumber ekonomi di wilayah pedesaan. Akses tersebut antara lain akses sarana dan prasarana pertanian, pengairan, jalan, usaha tani, pemasaran produksi, koperasi usaha tani, dan perbankan (kredit usaha rakyat).

3. Konsep Policy/Regulation reform, yakni berkenaan dengan pengaturan kebijakan dan hukum yang berpihak pada rakyat banyak. ${ }^{29}$

Penjelasan mengenai yang dimaksud dengan reformasi agraria di atas memperlihatkan bahwa reformasi agraria bukan hanya berbicara mengenai konflik pertanahan dan sumber daya alam, tetapi lebih luas lagi berbicara tentang regulasi atau pengaturan dan kebijakannya. Reformasi agraria tidak terlepas pula pada pembahasan wilayah desa karena berbagai persoalan tanah dan bidang pertanian

${ }^{28}$ Ben Cousins, Agrarian Reform and The Two Econimies: Transforming South Africa's Countryside, draft of chapter 9 in Ruth Hall and Laungisile Ntsebeza, eds., The Land Question in South Africa: The Challenge of Transformation and Redistribution, HSRC Press, Cape Town, South Africa, 2007, h. 30.

${ }^{29}$ Ibid, h. 31. 
ada di wilayah desa sehingga jika dikaitkan dengan masalah kebijakan, maka tentunya akan membahas mengenai otonomi daerah. Dalam Pasal 10 UndangUndang No. 32 Tahun 2004 tentang Pemerintah Daerah (UU No. 32/2004) dijelaskan mengenai pembagian urusan pemerintah pusat dan pemerintah daerah dimana masalah pertanahan menjadi kewenangan pemerintah daerah karena dalam Pasal 10 ini, yang ditentukan menjadi urusan pemerintah pusat hanya urusan politik luar negeri, pertanahan, keamanan, yustisi, moneter dan fiskal nasional, serta urusan agama. Di luar dari keenam urusan tersebut, selebihnya menjadi urusan daerah masing-masing daerah, termasuk urusan pertanahan dan pengelolaan sumber daya alam (agraria).

Dampak negatif dari adanya otonomi daerah ini adalah membuka kesempatan kepada oknum-oknum di pemerintah daerah untuk melakukan tindakan yang dapat merugikan negara dan rakyat, dan yang lebih berbahaya lagi adalah terkadang ada kebijakan daerah yang tidak sesuai dengan konstitusi negara. Sebagai contoh adalah pelaksanaan UU No. 5/1960 oleh pemerintah daerah, dengan sistem otonomi daerah maka pemerintah pusat akan sulit mengawasi jalannya kebijakan pertanahan di darah sehingga akan membuat peranan pemerintah pusat tidak begitu berarti padahal urusan pertanahan dan pengelolaan sumber daya alam mempunyai dampak langsung dan besar terhadap rakyat Indonesia. $^{30}$

Pada prinsipnya, otonomi daerah dapat menjadi sarana dan memberi peluang bagi pelaksanaan reforma agraria yang didukung dan didongkrak dari bawah, secara demokratis, atau reform by leverage. Untuk itu, organisasiorganisasi masyarakat khususnya petani harus berdaya sehingga mampu menjadi dongkrak yang kokoh bagi pelaksanaan reformasi agraria. Namun, hal ini harus pula didukung dan dijamin oleh konstitusi dan undang-undang sebagai payung nasional sehingga mampu merangsang keikutsertaan rakyat untuk melaksanakannya. Pemahaman yang perlu dihindari adalah penafsiran bahwa demi meningkatkan pendapatan daerah, pemerintah daerah kemudian merasa memiliki kewenangan untuk memperlakukan tanah sebagai komoditas. Jika

\footnotetext{
${ }^{30}$ Bernhard Limbong, Konflik Pertanahan, Jakarta: Margaretha Pustaka, 2012, h. 397.
} 
demikian, maka akan terdapat peluang terjadinya kolusi antar pemerintah daerah dan investor yang secara tidak langsung melahirkan era kolonialisme moderen ${ }^{31}$.

Bagi bangsa Indonesia hubungan manusia dengan tanah merupakan hal yang sangat mendasar dan asasi. Jika hal ini tidak tersusun dengan baik, akan lahir kemiskinan bagi sebagian terbesar rakyat Indonesia demikian pula akan terjadi ketidakadilan. Kemiskinan terutama disebabkan oleh lemahnya akses masyarakat terhadap sumber-sumber ekonomi dan sumber-sumber politik, termasuk yang terutama adalah tanah. Program Reformasi Agraria Nasional merupakan agenda besar dan mendasar untuk mengatasi kemiskinan yang mendera sebagian besar rakyat Indonesia dan sebagai alat untuk membawa bangsa Indonesia menuju kemakmuran dan kesejahteraan yang berkeadilan, sehingga tidak salah kalau dikatakan bahwa Program Reformasi Agraria Nasional adalah perwujudan dari pemenuhan hak-hak asasi manusia. Dalam implementasinya kemudian diperlukan kerjasama antara berbagai pihak pemangku kepentingan (stakeholders) yang terkoordinir dan bersatu. Selain itu juga perlu dikembangkan program-program yang dapat memperbaiki sistem, skema dan supporting system.

Berbicara tentang reformasi agraria salah satunya berbicara tentang kebijakan. Oleh karena itu, pembahasan tentang reformasi agraria senantiasa bersinggungan dengan kebijakan negara yang dalam hal ini pemerintah pusat. Di sisi lain, konteks agraria tidak terlepas pula dari wilayah pedesaan karena awalnya masalah agraria adalah masalah tanah pertanian yang fokusnya berada di desa. Dalam perkembangan zaman ini, fokus agraria bukan hanya sekedar tanah pertanian tetapi mencakup pula tanah non-pertanian, tidak hanya tanah di desa tetapi mencakup pula tanah perkotaan. Lebih luas lagi, masalah agraria bukan hanya berbicara tentang tanah, tetapi berbicara mengenai sumber daya alam.

Titik fokus dalam penulisan ini adalah reformasi agraria dalam kaitannya dengan ketatapemerintahan yang baik. Hal ini dirasa perlu untuk disinggung oleh karena berbicara reforma agraria adalah berbicara mengenai kebijakan pemerintah, baik pusat maupun daerah. Berbicara mengenai kebijakan, maka tentunya tidak terlepas pula pada tindakan pemerintah untuk mewujudkan ketatap

\footnotetext{
${ }^{31}$ Ibid, h. 400.
} 
pemerintahan yang baik. Lebih khusus lagi, penulis mencoba mengkaji keterkaitan antara partisipasi masyarakat dalam pelaksanaan reforma agraria di Indonesia. Tanah sebagai modal utama kemerdekaan Negara Kesatuan Republik Indonesia haruslah dikelola dengan baik sebagai amanah Pasal 33 ayat (3) UUD Negara Republik Indonesia 1945 dan UU No. 5/1960. Tanah merupakan sumber agraria yang diamanatkan kepada Negara untuk diatur pemilikannya dan memimpin penggunaannya bagi tanah-tanah di wilayah kedaulatan untuk kemakmuran yang berkeadilan baik secara perorangan maupun bersama-sama. Wilayah (Tanah), Rakyat, dan Pemerintah merupakan pilar keberadaan Negara, dan Tanah sebagai pilar yang strategis haruslah tertib administrasi dalam pengelolaannya sehingga antara Tertib Pertanahan dan Tertib Kependudukan terintegrasi dengan baik akan menghasilkan Tertib Pemerintahan (Pemerintahan Yang Baik).

Setelah lebih dari 50 tahun UU No. 5/1960 berjalan, ruang lingkup tanah dan artian wilayah menjadi semakin sempit hingga tinggal permukaan daratan saja. Dalam kenyataannya BPN yang seharusnya mengurusi tanah (wilayah), hanya mengurusi Sertipikat Tanah, itupun tidak optimal sebagaimana perintah undang-undang. Bidang Kehutanan yang seharusnya mengurusi pohon untuk hutan juga mengurusi tanah yang berdampak pelanggaran hukum pada pelepasan kawasan hutan. Keadaan tersebut menampakkan adanya disharmoni antara UU No. 5/1960 dengan undang-undang sektoral lainnya sehingga terjadi disharmonisasi koordinasi pelaksanaannya. Fakta dapat disaksikan bahwa terjadi pemborosan yang desertai ketidakoptimalan pengelolaan sumber-sumber agraria sebagai akibat tidak ada integrasi dan kecermatan dalam penggunaan dan pemanfaatannya.

Perlunya penataan kembali disharmoni kewenangan pengelolaan pertanahan dan sumber-sumber agraria pada tata kelola pemerintahan terintegrasi ke dalam satu lembaga yang sekaligus pula memperkuat dan memberdayakan peranan dan fungsi Badan Pertanahan Nasional sebagai satu-satunya lembaga pemerintahan yang mengurusi masalah pertanahan di Indonesia. Penataan tersebut 
harus berpondasi pada konstitusi sebagaimana termaktub dalam Pasal 33 ayat (3) UUD Negara Republik Indonesia 1945 dan UU No. 5/1960.

Di era otonomi daerah sekarang ini, masalah sentralisasi dan desentralisasi bukan lagi dipandang sebagai masalah penyelenggaraan negara saja sebab pada akhirnya kekuatan suatu bangsa harus diletakkan pada masyarakatnya. Birokrasi adalah alat bagi pemerintah pusat untuk melakukan perbaikan daerah. Birokrasi jika dirancang secara sungguh-sungguh bisa berperan sebagai alat untuk merasionalisasikan masyarakat. Secara negatif, pelaksanaan desentralisasi mempunyai efek yang sangat berlawanan dengan pengelolaan sumber daya alam. Desentralisasi akan mengarah pada eksploitasi dan kerusakan sumber daya alam tanpa adanya pendekatan yang baik. Otonomi telah menciptakan kesempatan untuk mengeksploitasi potensi daerah dan sekaligus menciptakan kesempatan yang luas pada kaum liberalisme untuk bertindak sesuka hatinya dengan berlindung pada dalil peningkatan pendapatan asli daerah. Namum sebaliknya, pelaksanaan otonomi yang dalam hal ini desentralisasi, dapat memaksimalkan potensi sumber daya alam di daerah apabila dilakukan dengan tetap mengindahkan aspek kelestarian dan kelangsungan alam. Oleh karena itu, prasyarat diperlukan demi tercapainya pengelolaan sumber daya alam yang berbasis komunitas lokal.

Good Governance sebagai suatu gerakan adalah segala daya upaya untuk mewujudkan suatu pemerintahan yang baik. Oleh karena itu gerakan good governance harus memiliki agenda yang jelas tentang apa yang mesti dilakukan agar tujuan utamanya dapat dicapai. Untuk kasus Indonesia, agenda good governance harus disesuaikan dengan kondisi riil bangsa saat ini, yang meliputi:

\section{Agenda Politik}

Masalah politik seringkali menjadi penghambat bagi terwujudnya good governance. Hal ini dapat terjadi karena beberapa sebab, di antaranya adalah acuan konsep politik yang tidak/kurang demokratis yang berimplikasi pada berbagai persoalan di lapangan. Krisis politik yang melanda bangsa Indonesia dewasa ini tidak lepas dari penataan sistim politik yang kurang demokratis. 
Oleh karena itu perlu dilakukan pembaharuan politik yang menyangkut masalah-masalah penting seperti:

a. Amandemen UUD 1945. Sebagai sumber hukum dan acuan pokok penyelenggaraan pemerintahan, amandemen UUD 1945 harus dilakukan untuk mendukung terwujudnya good governance seperti pemilihan presiden langsung, memperjelas susunan dan kedudukan MPR dan DPR, kemandirian lembaga peradilan, kemandirian kejaksaan agung dan penambahan pasal-pasal tentang hak asasi manusia.

b. Reformasi agraria dan perburuhan.

c. Mempercepat penghapusan peran sosial politik TNI.

d. Penegakan supremasi hukum.

\section{Agenda Ekonomi}

Krisis ekonomi bisa melahirkan berbagai masalah sosial yang bila tidak teratasi akan mengganggu kinerja pemerintahan secara menyeluruh. Untuk kasus Indonesia, permasalahan krisis ekonomi ini telah berlarut-larut dan belum ada tanda-tanda akan segera berakhir. Kondisi demikian ini tidak boleh dibiarkan berlanjut dan harus segera ada percepatan pemulihan ekonomi. Mengingat begitu banyak permasalahan ekonomi di Indonesia, perlu dilakukan prioritas-priotitas kebijakan. Prioritas yang paling mendesak untuk pemulihan ekonomi saat ini antara lain:

a. Agenda Ekonomi Teknis.

1) Otonomi Daerah. Pemerintah dan rakyat Indonesia telah membuat keputusan politik untuk menjalankan otonomi daerah yang esensinya untuk memberikan keadilan, kepastian dan kewenangan yang optimal dalam pengelolaan sumber daya daerah guna memungkinkan daerah dapat mengaktualisasikan segala potensi yang dimilikinya. Agar pelaksanaan otonomi daerah ini berjalan tanpa gejolak dibutuhkan serangkaian persiapan dalam bentuk strategi, kebijakan program dan persiapan institusi di tingkat pusat dan daerah.

2) Sektor Keuangan dan Perbankan. Permasalahan terbesar sektor keuangan saat ini adalah melakukan segala upaya untuk 
mengembalikan fungsi sektor perbankan sebagai intermediasi. Hal penting yang harus dilakukan antara lain; Pertama, diperlukan kinerja yang tinggi oleh karena tidak adanya dikotomi antara bank nasional dan bank asing, tidak peduli apakah hal itu dihasilkan oleh bank nasional ataupun asing. Kedua, perlu lebih mendorong dilakukannya merger atau akuisisi, baik di bank BUMN maupun swasta. Ketiga, pencabutan blanket guarantee perlu dipercepat, namun dilakukan secara bertahap. Keempat, mendorong pasar modal dan mendorong independensi pengawasan.

3) Kemiskinan dan Ekonomi Rakyat.

Pemulihan ekonomi harus betul-betul dirasakan oleh rakyat kebanyakan. Hal ini praktis menjadi prasarat mutlak untuk membantu penguatan legitimasi pemerintah, yang pada giliranya merupakan bekal berharga bagi percepatan proses pembaharuan yang komprehensif menuju Indonesia baru.

b. Agenda Pengembalian Kepercayaan. Hal-hal yang diperlukan untuk mengembalikan atau menaikkan kepercayaan terhadap perekonomian Indonesia adalah kepastian hukum, jaminan keamanan bagi seluruh masyarakat, penegakkan hukum bagi kasus-kasus korupsi, konsistensi dan kejelasan kebijakan pemerintah, integritas dan profesionalisme birokrat, disiplin pemerintah dalam menjalankan program, stabilitas sosial dan politik, dan adanya kepemimpinan nasional yang kuat.

3. Agenda Sosial

Masyarakat yang berdaya, khususnya dalam proses penyelenggaraan pemerintahan merupakan perwujudan riil good governance. Masyarakat semacam ini akan solid dan berpartisipasi aktif dalam menentukan berbagai kebijakan pemerintahan. Selain itu masyarakat semacam ini juga akan menjalankan fungsi pengawasan yang efektif dalam pelaksanaan penyelenggaraan pemerintahan. Sebaliknya, pada masyarakat yang masih belum berdaya di hadapan negara, dan masih banyak timbul masalah sosial di dalamnya seperti konflik dan anarkisme kelompok, akan sangat kecil 
kemungkinan good governance bisa ditegakkan. Salah satu agenda untuk mewujudkan good governance pada masyarakat semacam ini adalah memperbaiki masalah sosial yang sedang dihadapi.

Masalah sosial yang cukup krusial dihadapi bangsa Indonesia akhir-akhir ini adalah konflik yang disertai kekejaman sosial luar biasa yang menghancurkan kemanusiaan dan telah sampai pada titik yang membahayakan kelanjutan kehidupan dalam bentuk kekerasan komunal dan keterbuangan sosial dengan segala variannya. Kasus-kasus seperti pergolakan di Aceh dan Ambon adalah beberapa contoh dari masalah sosial yang harus segera mendapatkan solusi yang memadai. Oleh karena itu masyarakat bersama pemerintah harus melakukan tindakan pencegahan terhadap daerah lain yang menyimpan potensi konflik. Bentuk pencegahan terhadap kekerasan komunal dapat dilakukan melalui; memberikan santunan terhadap mereka yang terkena korban konflik, mencegah berbagai pertikaian -vertikal maupun horizontalyang tidak sehat dan potensial mengorbankan kepentingan bangsa dan mencegah pula segala bentuk anarkhi sosial yang terjadi di masyarakat.

4. Agenda Hukum

Hukum merupakan faktor penting dalam penegakan good governance. Kekurangan atau kelemahan sistim hukum akan berpengaruh besar terhadap kinerja pemerintahan secara keseluruhan. Dapat dipastikan, good governanance tidak akan berjalan mulus di atas sistim hukum yang lemah. Oleh karena itu penguatan sistim hukum atau reformasi hukum merupakan kebutuhan mutlak bagi terwujudnya good governance. Sementara itu posisi dan peran hukum di Indonesia tengah berada pada titik nadir, karena hukum saat ini lebih dianggap sebagai komiditi daripada lembaga penegak keadilan. Kenyataan demikian ini yang membuat ketidakpercayaan dan ketidaktaatan pada hukum oleh masyarakat. Untuk memulihkan kembali kepercayaan masyarakat terhadap hukum dalam rangka mewujudkan good governance diperlukan langkah-langkah kongkret dan sistimatis. Langkah-langkah tersebut adalah: 
a. Reformasi Konstitusi. Konstitusi merupakan sumber hukum bagi seluruh tata penyelenggaran negara. Untuk menata kembali sistim hukum yang benar perlu diawali dari penataan konstitusi yang oleh banyak kalangan masih banyak mengandung celah kelemahan.

b. Penegakan Hukum. Syarat mutlak pemulihan pepercayaan rakyat terhadap hukum adalah penegakan hukum. Reformasi di bidang penegakan hukum yang bersifat strategis dan mendesak untuk dilakukan adalah; Pertama, reformasi Mahkamah Agung dengan memperbaiki sistim rekrutmen (pengangkatan), pemberhentian, pengawasan dan penindakan yang lebih menekankan aspek transparansi dan partisipasi masyarakat. Perbaikan sebagaimana tersebut tersebut harus dilakukan oleh Komisi Yudisial yang independen. Kedua, reformasi Kejaksaan. Untuk memulihkan kinerja kejaksaan saat ini khususnya dalam menangani kasus-kasus KKN dan pelanggaran HAM, perlu dilakukan fit and proper test terhadap Jaksa Agung dan pembantunya sampai eselon II untuk menjamin integritas pribadi yang bersangkutan. Selain itu untuk mengawasi kinerja kejaksaan perlu dibentuk sebuah komisi Independen Pengawas Kejaksaan.

c. Pemberantasan Korupsi, Kolusi, dan Nepotisme (KKN). KKN merupakan penyebab utama dari tidak berfungsinya hukum di Indonesia. Untuk memberantas KKN diperlukan setidaknya dua cara, yakni pencegahan (preventif) dan penanggulangan (represif). Upaya pencegahan dilakukan dengan cara memberi jaminan hukum bagi perwujudan pemerintahan terbuka (open government) dengan memberikan jaminan kepada hak publik seperti hak mengamati perilaku pejabat, hak memperoleh akses informasi, hak berpartisipasi dalam pengambilan keputusan dan hak mengajukan keberatan bila ketiga hak di atas tidak dipenuhi secara memadai. Sedangkan upaya penanggulangan (setelah korupsi muncul) dapat diatasi dengan memaksimalkan kinerja Komisi Pemberantasan Korupsi (KPK), memperkenalkan hakim-hakim khusus yang diangkat khusus untuk kasus korupsi (hakim ad hoc) dan memperlakukan asas pembuktian terbalik secara penuh. 
d. Sumbangan hukum dalam mencegah dan menanggulangi disintegrasi bangsa. Pengakuan identitas terhadap nilai-nilai lokal, pemberian kewenangan dan representasi yang lebih luas kepada daerah, pemberdayaan kemampuan masyarakat dan akses pengelolaan terhadap sumber daya alam lokal menjadi isu penting yang sangat stategis di dalam menciptakan integritas sosial, karena selama ini masyarakat selalu ditempatkan sebagai obyek, tidak diakui berbagai eksistensinya dan diperlakukan tidak adil. Akumulasi dari permasalahan tersebut akhirnya menciptakan potensi yang sangat signifikan bagi proses disintegrasi.

e. Pengakuan terhadap hukum adat dan hak ekonomi masyarakat. Untuk menjamin hak-hak masyarakat hukum adat, maka diperlukan proses percepatan di dalam menentukan wilayah hak ulayat adat secara partisipatif. Dengan begitu, rakyat akan mendapatkan jaminan di dalam menguasai tanah ulayat adat mereka dan juga akses untuk mengelola sumber daya alam di lingkungan dan milik mereka sendiri.

f. Pemberdayaan eksekutif, legislatif dan peradilan. Untuk lebih meningkatkan representasi kepentingan daerah di tingkat nasional, perlu dilakukan rekomposisi keanggotaan utusan daerah dimana keterwakilan rakyat di daerah secara kongkret diakomodasi melalui pemilihan anggota utusan daerah secara langsung oleh rakyat. Penerapan penegak hukum harus dilakukan secara kontekstual dengan menggunakan kebijakan selektive enforcement sehingga keadilan memang berasal dari rasa keadilan yang hidup di masyarakat.

Pentingnya melakukan reformasi agraia sebagai salah satu solusi mengatasi persoalan kemiskinan agraria ternyata tidak mudah untuk diterjemahkan secara praktis. Proses penataan struktur agraria, selain memerlukan kekuatan politik pemerintah yang solid (termasuk militer) juga memerlukan informasi yang memadai menyangkut persoalan dan potensi agraria itu sendiri. Tanpa informasi yang memadai, agenda reformasi agraria hanya akan menjadi slogan politik yang sulit direalisasikan. Pada sisi lain, perkembangan sosial politik yang terjadi selama ini (termasuk perkembangan metodologi) menuntut adanya 
partisipasi masyarakat dalam proses pelaksanaan reformasi agraria. Pelaksanaan reformasi agraria tidak bisa sepenuhnya menggunakan kewenangan dan kekuatan pilitik pemerintah semata, akan tetapi perlu juga melibatkan partisipasi masyarakat dan pihak-pihak lain yang terkait denganh pelaksanaan reformasi agraria. Oleh karena itu pula, maka proses identifikasi masalah, penggalian potensi, serta identifikasi model reformasi agraria selayaknya dilakukan secara partisipatif. Terlebih lagi dalam konteks otonomi daerah, kewenangan pelaksanaan landreform menjadi kewenangan daerah sehingga keterlibatan masyarakat sejak awal perlu mendapatkan penekanan yang serius.

Perlu adanya kerelaan dan penegasan kewenangan pusat dan daerah, sehingga menjadi jelas pertanggungjawabannya masing-masing, utamanya dalam alokasi dan manjemen sumber-sumber daya agraria. Apabila reformasi agraria dipilih sebagai suatu pilihan kebijakan restrukturisasi pemilikan/penguasaan dan pemanfaatan tanah serta sumber daya alam lainnya, maka diperlukan suatu lembaga pendukung yang dapat memfasilitasi pelaksanaannya, mengkoordinasikan menyelesaikan sengketa yang timbul dari pelaksanaannya. Paradigma lama yang bercirikan sentralisme dalam pembuatan kebijakan telah menafikan partisipasi. Tradisi sosialisasi terhadap RUU/RPP/Raperda akan lebih baik apabila metode konsultasi publik lebih dioptimalkan dalam setiap tahapan pembuatannya, sehingga terwujud yang disebut dengan partisipasi interaktif dan bukan partisipasi pasif seperti yang terjadi pada saat ini.

Sebagaimana telah dikemukakan sebelumnya bahwa berbicara reforma agraria tidak lepas pada persoalan desa dimana pelaksanaan reforma agraria tidak terlepas pada konteks pengembangan desa dan masyarakat desa. Pengembangan wilayah pedesaan di Indonesia telah banyak dilakukan sejak dari dulu hingga saat ini, namun hasilnya belum memuaskan terhadap peningkatan kesejahteraan masyarakat pedesaan. Pengembangan wilayah desa seharusnya dilihat bukan hanya sebagai objek tetap juga harus dilihat sebagai subjek pengembangan. Sasaran pengembangan wilayah pedesaan yang ingin tercipta pada dasarnya adalah:

a. Peningkatan produksi dan produktivitas 
b. Percepatan pertumbuhan desa

c. Peningkatan keterampilan dalam berproduksi dan pengembangan lapangan kerja dan lapangan usaha produktif.

d. Peningkatan prakarsa dan partisipasi masyarakat.

e. Perkuatan kelembagaan.

f. Pengembangan wilayah pedesaan yang dilaksanakan harus sesuai dengan masalah yang dihadapi, potensi yang dimiliki, serta aspirasi dan prioritas masyarakat pedesaan.

Adapun pengembangan pedesaan mempunyai ruang lingkup, yakni:

a. Pembangunan sarana dan prasarana pedesaan (meliputi pengairan, jaringan jalan, lingkungan permukiman dan lainnya).

b. Pemberdayaan masyarakat.

c. Pengelolaan sumberdaya alam (SDA) dan sumber daya manusia (SDM).

d. Penciptaan lapangan kerja, kesempatan berusaha, peningkatan pendapatan (khususnya terhadap kawasan-kawasan miskin).

e. Penataan keterkaitan antar kawasan pedesaan dengan kawasan perkotaan (inter rural-urban relationship).

Pengembangan wilayah pedesaan seharusnya menerapkan prinsip-prinsip good governance sehingga pembangunan betul-betul mengarah pada perwujudan kesejahteraan masyarakat. Jika wilayah dan masyarakat desa dapat dikembangkan, maka tentunya akan menopang pelaksanaan reformasi agraria di Indonesia sehingga pada akhirnya pelaksanaan reforma agraria dapat berjalan secara maksimal dengan melibatkan seluruh komponen negara yang ada, mulai dari pemerintah, lembaga-lembaga negara atau lembaga pemerintah dan nonpemerintah sampai kepada lapisan masyarakat terbawah.

Perencanaan Program Reformasi Agraria Nasional harus disesuaikan dengan karakteristik suatu wilayah. dengan melibatkan masukan stakeholders di wilayah mana akan dilaksanakan program, karena mereka lebih mengerti dengan kondisi wilayah mereka sehingga kegiatannya lebih fokus dengan permasalahan yang dihadapi daerah tersebut. Dengan demikian perencanaan yang baik akan 
membawa program ke arah yang sesuai dengan tujuan. Melaksanakanan pengendalian yang meliputi:

1. Menetapkan standar. Untuk memastikan pelaksanaan program dan subyek benar-benar membawa ke arah tujuan yang telah ditetapkan maka diperlukan standar baku yang berlaku umum tapi tetap memperhatikan kekhasan suatu wilayah.

2. Melakukan Kontrol dan Monitoring untuk mengantisipasi apabila di tengah perjalanan Program Reformasi Agraria Nasional terdapat hal-hal situasi baru, seperti adanya temuan penyimpangan, sehingga dapat keputusan segera untuk mengatasi hal tersebut dengan melibatkan semua pihak termasuk mengikutsertakan subyek dan stakeholders lainnya.

3. Melaksanakan Evaluasi untuk mengidentifikasi kelemahan, mendeteksi penyimpangan dan mengurangi kesalahan dari Program Reformasi Agraria Nasional serta memberikan saran. Kalau memang diperlukan melibatkan pihak auditor independen untuk menilai program, apakah telah sesuai dengan sesuai dengan tujuan semula. Dalam evaluasi juga harus dinilai sejauhmana partisipasi rakyat/subyek berperan dalam keberhasilan program, karena adanya partisipasi akan menstimulir rakyat/subyek untuk ikut bertanggungjawab terhadap program yang berimplikasi terhadap kehidupan rakyat atau petani.

\section{Kesimpulan}

Tanah sebagai modal utama kemerdekaan Negara Kesatuan Republik Indonesia haruslah dikelola dengan baik sebagai amanah Pasal 33 ayat (3) UUD Negara Republik Indonesia 1945 dan UU No. 5/1960. Otonomi daerah jelas harus dilakukan untuk menciptakan suatu kemandirian dalam usaha mengembangkan sumber daya alam yang dimiliki oleh masing-masing daerah. Good Governance sebagai suatu gerakan adalah segala daya upaya untuk mewujudkan suatu pemerintahan yang baik. Oleh karena itu gerakan good governance harus memiliki agenda yang jelas tentang apa yang mesti dilakukan agar tujuan utamanya dapat dicapai. 
Pentingnya melakukan reformasi agraia sebagai salah satu solusi mengatasi persoalan kemiskinan agraria ternyata tidak mudah untuk diterjemahkan secara praktis. Proses penataan struktur agraria, selain memerlukan kekuatan politik pemerintah yang solid (termasuk militer) juga memerlukan informasi yang memadai menyangkut persoalan dan potensi agraria itu sendiri. Tanpa informasi yang memadai, agenda reformasi agraria hanya akan menjadi slogan politis yang sulit direalisasikan. Pada sisi lain, perkembangan sosial politik yang terjadi selama ini (termasuk perkembangan metodologi) menuntut adanya partisipasi masyarakat dalam proses pelaksanaan reformasi agraria. Pelaksanaan reformasi agraria tidak bisa sepenuhnya menggunakan kewenangan dan kekuatan politik pemerintah semata, akan tetapi perlu juga melibatkan partisipasi masyarakat dan pihak-pihak lain yang terkait denganh pelaksanaan reformasi agraria. Oleh karena itu pula, maka proses identifikasi masalah, penggalian potensi, serta identifikasi model reformasi agraria selayaknya dilakukan secara partisipatif. Terlebih lagi dalam konteks otonomi daerah, kewenangan pelaksanaan landreform menjadi kewenangan daerah sehingga keterlibatan masyarakat sejak awal perlu mendapatkan penekanan yang serius.

Perencanaan Program Reformasi Agraria Nasional harus disesuaikan dengan karakteristik suatu wilayah. dengan melibatkan masukan stakeholders di wilayah mana akan dilaksanakan program, karena mereka lebih mengerti dengan kondisi wilayah mereka sehingga kegiatannya lebih fokus dengan permasalahan yang dihadapi daerah tersebut. Dengan demikian perencanaan yang baik akan membawa program ke arah yang sesuai dengan tujuan.

\section{Daftar Bacaan}

Abdullah, Kasman, "Penyelenggaraan Pemerintahan Dalam Konsep Good Governance" Jurnal Meritokrasi Vol. 1 No. 1, Fakultas Hukum Universitas Hasanuddin, Makassar, 2002.

Asshiddiqie, Jimly, Konstitusi dan Konstitusionalisme Indonesia, Jakarta: PSHTN FHUI, 2004. 
, Format Kelembagaan Negara dan Pergeseran Kekuasaan Dalam UUD 1945. Yogyakarta: FH UII Press, 2005.

Djatmiati, Tatiek Sri, Perizinan sebagai Instrumen Yuridis Dalam Pelayanan Publik, Pidato Pengukuhan Guru Besar Dalam Bidang Hukum Administrasi Pada Fakultas Hukum Universitas Airlangga di Surabaya, tanggal 24 November 2007.

Hadjon, Philipus M. et.all., Hukum Administrasi dan Good Governance, Cetakan Kedua, Jakarta: Penerbit Universitas Trisakti, 2012.

Limbong, Bernhard, Reforma Agraria, Jakarta: Margaretha Pustaka, 2012.

Konflik Pertanahan, Jakarta: Margaretha Pustaka, 2012.

Marbun, SF. dan Moh. Mahfud MD, Pokok-Pokok Hukum Administrasi Negara, Yogyakarta: Liberty, 2000.

Sedarmayanti, Good Governance (Kepemerintahan Yang Baik), Cetakan Kedua. Bandung: Mandar Maju, 2004.

Wiradi, Gunawan, Reformasi Agraria; Perjalanan Yang Belum Berakhir, Yogyakarta: INSIST Press, 2000.

Widodo, Joko, Good Governance; Telaah Dari Dimensi Akuntabilitas, Kontrol Birokrasi Pada Era Desentralisasi Dan Otonomi Daerah, Surabaya: Insan Cendekia, 2001. 